CHOUCAS 



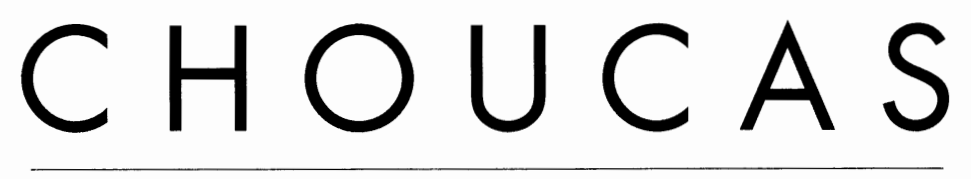

A N I NTERNATIONALNOVEL

\section{Zofia Nałkowska}

T R A N S L A T E D B Y U R S U L A P H I L L I P S 
(C) 2014 by Northern Illinois University Press

Published by the Northern Illinois University Press, DeKalb, Illinois 60115

All Rights Reserved

Design by Shaun Allshouse

Library of Congress Cataloging-in-Publication Data

Nalkowska, Zofia, 1884-1954.

[Choucas. English]

Choucas / Zofia Nalkowska ; translated by Ursula Phillips.

pages $\mathrm{cm}$

Summary: «English translation of a novel by Zofia Nalkowska, originally published in serial form in 1926, and then in book form in 1927. Set in a village in the Swiss Alps in the mid-1920s, the female narrator and her male companion, both Polish, are staying at a pension-cum-sanitorium. The focus is not on them as Poles but on the international community and the interaction between the community of the sick and of the winter sports> clientele who represent various nations»-Provided by publisher.

Includes bibliographical references.

ISBN 978-0-87580-707-2 (paperback) - ISBN 978-1-60909-160-6

(e-book)

I. Phillips, Ursula, translator. II. Title.

PG7158.N34C4613 2014

893. $8^{\prime} 536-\mathrm{dc} 23 \quad 2014007231$ 